\title{
Cereal bar sweetened with stevia leaves reduces fatty liver in diabetic rats
}

\author{
Sandra Beserra da Silva ${ }^{1} \oplus$, Luana Marcelly Martins ${ }^{1} \oplus$, Silvano Piovan ${ }^{1}$, Paula Gimenez Milan ${ }^{1} \oplus$, \\ João Paulo Gonçalves da Costa Silva' ${ }^{1}$, Flávio Augusto Vicente Seixas ${ }^{1} \oplus$, \\ Cecília Edna Mareze-Costa ${ }^{1}$, Silvio Cláudio da $\operatorname{Costa}^{1}{ }^{1}$

\footnotetext{
1 Universidade Estadual de Maringá, Maringá, PR, Brasil. E-mail: sandrabeserrab@gmail.com; ra107338@uem.br; silvanopiovan23@gmail.com; pgmfernandes2@uem.br; jgoncalvezdacostasilva@gmail.com; favseixas@gmail.com; cemcosta@uem.br; sccosta@uem.br
}

ABSTRACT: Diabetes mellitus and hepatic steatosis are diseases of great epidemiological impact and have been associated with increased consumption of sugary foods and drinks. The objective of this work was to evaluate the effect of food supplementation with cereal bars sweetened with Stevia rebaudiana leaves pretreated with ethanol (SLPE) on the metabolic control of streptozotocininduced diabetic rats. Two cereal bar formulations were developed: one sweetened with SLPE, and the other sweetened with sucrose. The cereal bars were added to the standard ration for rodents $(125 \mathrm{~g}: 1000 \mathrm{~g})$ and offered ad libitum to diabetic animals for 30 days. Important physiological parameters were recorded during and at the end of this period for metabolic control (body weight, food intake, glycemia, fructosamine, triglycerides, cholesterol, AST, ALT, liver fat and glucose tolerance). The diet supplemented with cereal bars sweetened with SLPE significantly reduced the amount of liver fat in diabetic rats, suggesting the potential of cereal bars sweetened with SLPE to act as a functional food for diabetic patients.

Key words: cereal bar; diabetes; fatty liver; Stevia rebaudiana

\section{Barra de cereal adoçada com folhas de stevia reduz esteatose hepática em ratos diabéticos}

RESUMO: O diabetes mellitus e a esteatose hepática são doenças de grande impacto epidemiológico e tem sido associada ao aumento de consumo de alimentos e bebidas açucaradas. $O$ objetivo desse trabalho foi avaliar o efeito da suplementação alimentar com barras de cereais, adoçadas com folhas de Stevia rebaudiana pré-tratadas com etanol (SLPE), no controle metabólico de ratos diabéticos induzidos por estreptozotocina. Foram desenvolvidas duas formulações de barras de cereais, uma adoçada com SLPE e a outra adoçada com sacarose. As barras de cereais foram adicionadas à ração padrão para roedores (125g:1000g) e oferecidas ad libitum aos animais diabéticos, por 30 dias. Durante e ao final deste período, foram registrados parâmetros fisiológicos importantes para o controle metabólico (peso corporal, ingestão alimentar, glicemia, frutosamina, triglicerídeos, colesterol, AST, ALT, gordura hepática e tolerância à glicose). A ração suplementada com barras de cereais adoçadas com SLPE reduziu significativamente a quantidade de gordura hepática de ratos diabéticos, sugerindo a potencialidade das barras de cereais adoçadas com SLPE atuarem como um alimento funcional para pacientes diabéticos.

Palavras-chave: barra de cereal; diabetes; gordura; Stevia rebaudiana 


\section{Introduction}

Stevia rebaudiana Bert. (Bertoni) is a shrub plant native from South America and its leaves, stems and inflorescences have high intensity sweeteners known as steviol glycosides, with an emphasis on stevioside and rebaudioside $A$, which are used as non-caloric sweeteners in diet and light food and drinks, replacing carbohydrates such as sucrose and fructose or artificial sweeteners. However, an aspect which hinders the acceptance of stevia sweeteners is the presence of an "aftertaste" or a bitter aftertaste (Dacome et al., 2005; Hubert et al., 2015). One of the strategies to reduce or eliminate the undesirable taste of stevia products is the process of pretreating stevia leaves with ethanol. Stevia leaves pretreated with ethanol (SLPE) can be used as starting material to obtain stevia extracts with superior sensory quality, as reported by Formigoni et al. (2018), or can be used directly as ingredients in formulating food products with the aim of sweetening and incorporating functional bioactive, such as the SLPEsweetened cereal bar developed by Silva et al. (2019).

Stevia, its extracts, fractions or isolated compounds, including sweetening glycosides, also have functional properties. The most investigated among stevia's alreadyfound features have been its hypoglycemic and antidiabetic effects (Jeppesen et al., 2002; Raskovic et al., 2004). Such features added to the property of sweetening without adding calories make this plant a natural product source of great interest, as it has the potential to promote developing innovative foods or ingredients which can contribute to treating metabolic diseases such as diabetes mellitus (DM).

DM is a chronic disease of multifactorial etiology caused by defects in the secretion and/or in the action of insulin and whose main manifestation is hyperglycemia (Harlev et al., 2013). Complex disorders occur in this disease which compromise the metabolism of carbohydrates, proteins and lipids, resulting in multiple functional changes which can result in the occurrence of several diseases in the long run (DM complications), such as retinopathies (Payne et al., 2014), nephropathies (Pálsson \& Patel, 2014), vascular, as well as articular and bone diseases (Sponer et al., 2013), characterizing DM as a syndrome of high morbidity and mortality.

The treatment of DM is complex as it consists of special diets, physical exercise and constant hyperglycemia control (Sponer et al., 2013). The high number of carriers, the difficult treatment and the serious associated diseases have stimulated numerous studies which have sought sources for medications or functional foods which can help in preventing or treating DM.

The demand for healthy foods has driven industries to invest into this segment, innovating the insertion of functional ingredients (Pinto, 2017). This growing concern for healthy eating places some foods and ingredients on the research list for developing new products (Ciuli et al., 2017). In this context, diet cereal bars have gained prominence in the market for presenting several health benefits (Srebernich et al., 2011), providing convenience for consumption and serving those who need to reduce their sugar intake (Castro \& Franco, 2002).
In developing cereal bars sweetened with SLPE, Silva et al. (2019) achieved significant advances in nutritional and sensory aspects, along with good purchase acceptance of the final product. The pretreatment process of stevia leaves with ethanol selectively removes compounds responsible for the bitter aftertaste, such as labdanic diterpenes, preserving the sweetener and phenolic compound content with significant antioxidant activity in the SLPE.

Within this context, the objective of this work was to investigate the hypothesis that rations supplemented with cereal bars sweetened with SLPE present functional properties which help in the metabolic control of DM in experimental models of diabetic animals.

\section{Materials and Methods}

Formulation of cereal bars: The cereal bars were produced at the Product Processing Laboratory of the State University of Maringá (UEM), Umuarama - PR campus, according to the methodology described by Silva et al. (2019). The sucrose or pretreated stevia leaf percentage used to sweeten the cereal bars was $1.8 \%$ (Table 1 ).

Feed formulation for rats: Two formulations were produced, one called FSTV - feed supplemented with pretreated stevia leaves, and the other called FSAC - feed supplemented with cereal bar sweetened with sucrose. Standard Nuvilab rodent feed (RF) was used, which together with the cereal bars were ground in a knife mill with $5 \mathrm{~mm}$ diameter sieves in the proportion of five cereal bars $(25 \mathrm{~g}$ each) for 1,000g of or (125g:1000g or 1:8). After crushing, the mixture was moistened, fractionated into small pellets and stored in a cool, light-free place. Table 2 shows the proximate composition of the three diets used in the rats' feed.

Table 1. Composition of cereal bars.

\begin{tabular}{lc}
\hline \multicolumn{1}{c}{ Ingredients } & Quantity (\%) \\
\hline Oat flakes & 18 \\
Granola (mix of dried fruits and cereals) & 29 \\
Dehydrated apricot & 9 \\
Dehydrated cranberry & 9 \\
Gum & 8.2 \\
Water & 25 \\
SLPE* or sucrose & 1.8 \\
\hline
\end{tabular}

*SLPE: Stevia leaves pretreated with ethanol.

Table 2. Centesimal composition of standard rodent feed (Nuvilab ${ }^{\circ}$ ) supplied by the manufacturer and estimated centesimal composition of supplementary diets with cereal bars sweetened with stevia leaves pretreated with ethanol or sucrose.

\begin{tabular}{lccc}
\hline \multicolumn{1}{c}{ Composition } & RF & FSTV & FSAC \\
\hline Carbohydrates $\left({\left.\mathrm{g} \times 100 \mathrm{~g}^{-1}\right)}^{-1}\right.$ & 51.5 & 52.7 & 52.8 \\
Proteins $\left(\mathrm{g} \times 100 \mathrm{~g}^{-1}\right)$ & 22.0 & 20.9 & 20.9 \\
Lipids $\left(\mathrm{g} \times 100 \mathrm{~g}^{-1}\right)$ & 4.0 & 3.8 & 3.8 \\
Moisture $\left(\mathrm{g} \times 100 \mathrm{~g}^{-1}\right)$ & 12.5 & 12.7 & 12.5 \\
Ashes $\left(\mathrm{g} \times 100 \mathrm{~g}^{-1}\right)$ & 10.0 & 9.1 & 9.1 \\
\hline
\end{tabular}

RF: Rodent feed; FSTV: Feed + Cereal bar sweetened with stevia leaves; FSAC: Feed + Cereal bar sweetened with sucrose. The RF composition was supplied by the manufacturer, while the FSTV and FSAC compositions were estimated from the RF data and the composition of the stevia leaves pretreated with ethanol (Silva et al., 2019). 
Experimental Animals: 35 male Wistar rats at 60 days old from the Central Biottherium of the State University of Maringá were used. The animals were kept in the Sectoral Biottherium of the Department of Physiological Sciences under the following conditions: temperature of $23^{\circ} \mathrm{C}, 12$-hour light/12hour dark photoperiod, water and feed (Nuvilab- Colombo $\mathrm{PR}$ ) ad libitum. The animals were kept in collective cages (46 $\mathrm{x}$ $24 \times 20 \mathrm{~cm}$ ), 5 animals per cage. The experimental protocol was approved by the Ethics Committee on the Use of Animals at the State University of Maringá (CEUA no 5069240818).

Diabetes induction and establishment of experimental groups: For the induction of experimental diabetes, 60-dayold rats fasting overnight for 12 hours were anesthetized (thiopental $40 \mathrm{mg}$ + lidocaine $10 \mathrm{mg} \mathrm{kg}^{-1}$, i.p.) and then received a single intravenous application (penile vein) of streptozotocin (Sigma; $40 \mathrm{mg} \mathrm{kg}^{-1}$ p.c.), dissolved in citrate buffer (0.05M; pH 4.5), and were then fasted for another four hours after application. Animals which had fasting blood glucose equal to or greater than $200 \mathrm{mg} \mathrm{dL}^{-1}$ and blood glucose in the fed condition equal to or greater than 300 $\mathrm{mg} \mathrm{dL}^{-1}$ were then selected on the third day after diabetes induction. These glycemic values and also the body weight were the parameters used to establish three experimental groups of diabetic animals with similar degrees of severity of the induced diabetes. A group of non-diabetic animals was also included, therefore with four experimental groups in total: 1) ND ( $n=5)$ - non-diabetic animals fed with pure feed; 2) DC ( $n=10)$ - diabetic control animals fed pure feed; 3) DSTV $(n=10)$ - diabetic animals fed with feed added with cereal bars sweetened with stevia leaves pretreated with ethanol; 4) DSAC ( $n=10)$ - diabetic animals fed with food supplemented with cereal bars sweetened with sucrose. The experimental period was 30 days and food consumption and body weight were recorded weekly.

Oral glucose tolerance test (OGTT): At the end of the experimental period, the animals fasted at night were subjected to the oral glucose tolerance test. After blood collection (caudal puncture) for blood glucose at zero time (fasting), the animals received an overload of glucose $(1.5 \mathrm{~g} \mathrm{~kg}$ $\left.{ }^{1}\right)$ via esophageal gavage. New blood samples were collected at times 5, 15, 30, 45, 60, 90 and 120 minutes after glucose overload. Blood glucose was determined on a glucometer (MediSence Optium ${ }^{\circ}$ ).

Euthanasia and blood collection: after an overnight fast, the animals were euthanized by anesthetic overload (sodium thiopental, $120 \mathrm{mg} \mathrm{kg}^{-1}$, i.p) and submitted to median laparotomy. Blood samples were collected through the inferior vena cava, centrifuged and the serum and plasma were stored in a freezer at $-20^{\circ} \mathrm{C}$ and used to measure blood parameters. Then, the liver was dissected and weighed.

Fat content in the liver: After determining the total weight of the liver, one of the lobes was removed, weighed, stored in a $-20^{\circ} \mathrm{C}$ freezer and subsequently used for fat extraction following the method established by Folch et al. (1957). The triglyceride concentration in the sample was quantified by colorimetric methods (Gold Analisa Belo Horizonte, MG) and spectrophotometry (Bioplus2000', São Paulo, SP).

Plasma and serum parameters: Blood glucose, fructosamine, total cholesterol, triglycerides, aspartate aminotransferase (AST) and alanine aminotransferase (ALT) concentrations were determined by colorimetric methods (Gold Analisa Belo Horizonte, MG) and spectrophotometry (Bioplus2000 ${ }^{\circ}$, São Paulo, SP).

Statistical analysis: The results are presented as mean \pm standard error of the mean (SEM) and were subjected to analysis of variance, followed by the Tukey post-test $(p<0.05)$. The SAS version 9.1 and Graph Pad Prism version 5.0 statistical programs were used.

\section{Results and Discussion}

In Figure 1 it can be seen that the groups of diabetic animals that received the diet supplemented with cereal bars (DSTV and DSAC) had significantly higher feed intake (g day ${ }^{-1}$ ) than the groups of animals that received the pure diet (ND and $D C$ ), with the AUC values (area under the curve) being significantly different $(p<0.05)$. This fact is probably due to the greater palatability of the food due to the cereal bars. It is also noted that there was no difference in feed consumption between the DSTV and DSAC groups, showing that the two formulations had the same consumption acceptance by the experimental animals.

Despite the fact that the diabetic rats in the DSTV and DSAC groups had ingested a greater amount of feed, it can be seen (according to Figure 2) that the body weight was similar to

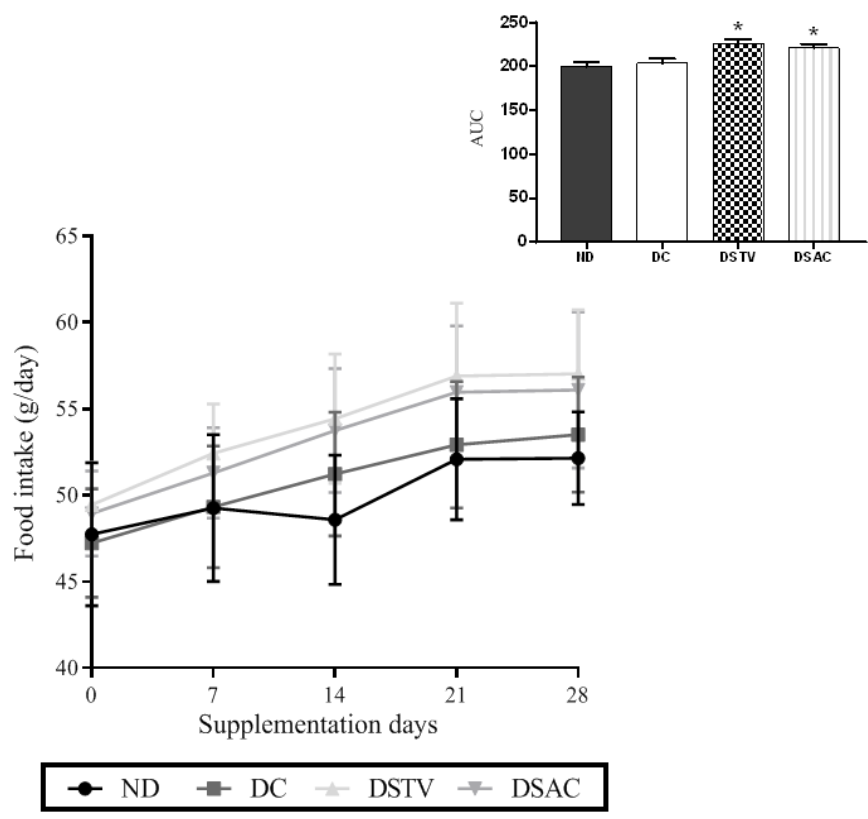

Figure 1. Effect of food supplementation with cereal bars sweetened with stevia leaves pretreated with ethanol or sucrose on the dietary intake of diabetic rats. In particular, the area under the curve (AUC). Data are expressed as mean \pm SEM. * differs from ND and DC $(p<0.05)$ - Analysis of variance followed by the Tukey test. 


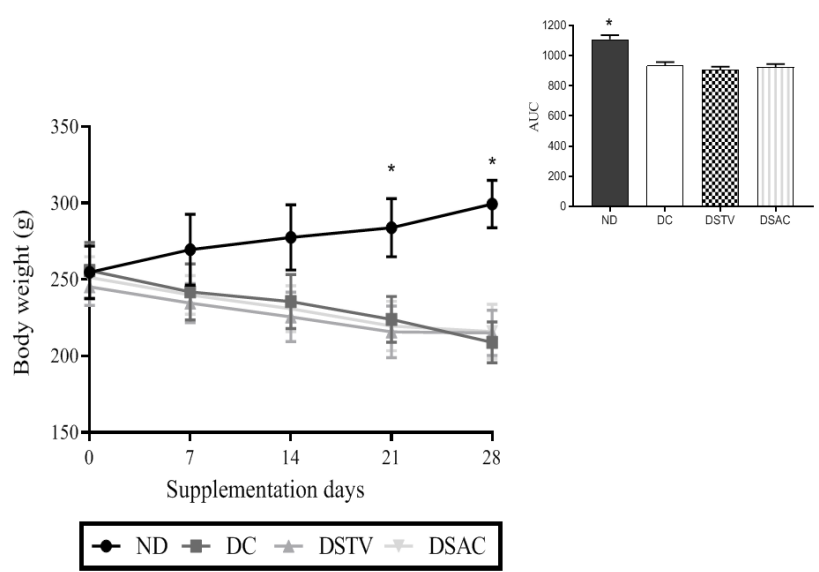

Figure 2. Effect of dietary supplementation with cereal bars sweetened with stevia leaves pretreated with ethanol (SLPE) or with sucrose on the body weight of diabetic rats. In particular, the area under the curve (AUC). Data were expressed as mean \pm SEM. $*$ differs from the other groups $(p<0.05)$. Analysis of variance followed by the Tukey test.

A

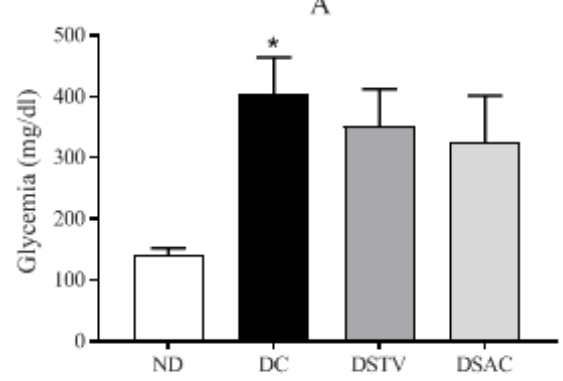

C

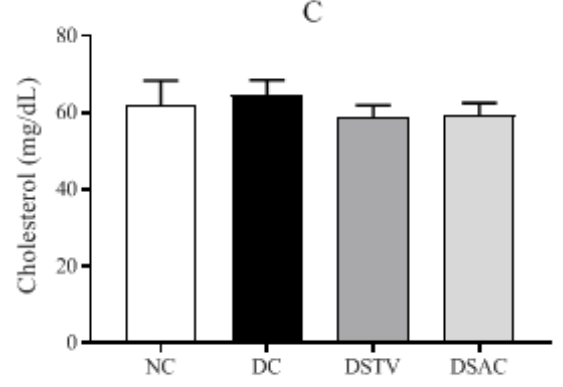

E

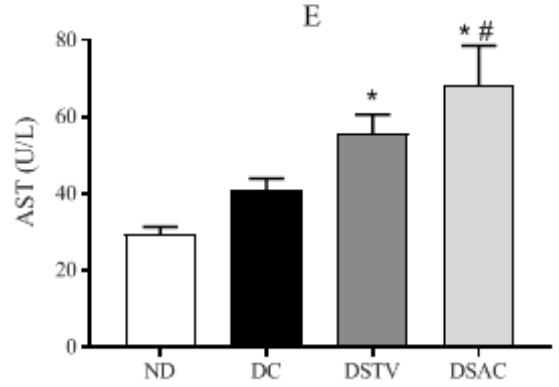

the DC group. It was also found that the non-diabetic animals (group ND) gained weight, while the three diabetic animal groups (DC, DSTV and DSAC) lost weight. Weight loss in this experimental model of streptozotocin-induced diabetes is a striking feature, which defines such a model with similarities to type 1 DM in humans (Rees \& Alcolado, 2015). Streptozotocin is a glucosamine-nitrosurea which promotes an increase in oxidative stress and cell death after being captured by pancreatic beta cells, causing a reduction in insulin secretion and the consequent metabolic changes (Silva et al., 2011). Among these changes is an intense catabolic condition resulting from the strong lipolytic activity (fat mass loss) and proteolytic activity (muscle mass loss) with the body weight loss.

It appears that the three groups of diabetic animals had fasting hyperglycemia (Figure 3A). Food supplementation with cereal bars did not cause significant effects on this parameter.

Hyperglycemia is one of the first clinical changes in DM. This is due to the fact that glucose to be transported into cells needs a membrane protein called GLUT (glucose transporter).
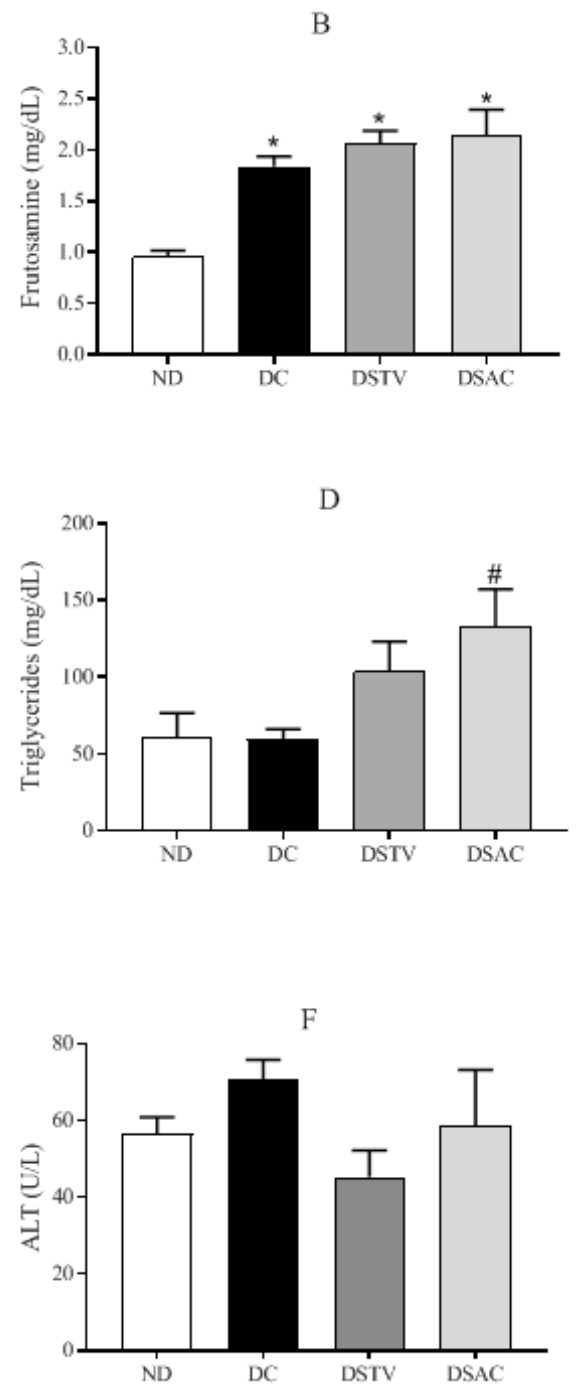

Figure 3. Effect of dietary supplementation with cereal bars sweetened with stevia leaves pretreated with ethanol (SLPE) or with sucrose for a period of 30 days on the plasma and serum parameters of diabetic rats in an overnight fasting state: (A) Glycemia; (B) Frutosamine; (C) Cholesterol; (D) Triglycerides; (E) AST; (F) ALT. The data represent mean \pm SEM. * differs from ND; \# differs from DC; $p<0.05$ - Analysis of variance followed by the Tukey test. 
Muscle and fat cells have a transporter subtype (GLUT4) which is only available in the plasma membrane in the presence of insulin. Thus, the lack of insulin or its action results in a significant reduction in the transport and use of glucose by muscle and fat cells (among other important changes), and as a consequence in hyperglycemia (Vargas et al., 2020).

Prolonged hyperglycemia causes a series of physiological disorders, including non-enzymatic glycation of proteins and consequent alteration of their functions. Thus, another parameter evaluated in this study was the serum fructosamine concentration (Figure 3B), which is a glycemic control marker which assesses the average glycemic level of two to three weeks prior to collection (Nansseu et al., 2015).

The term fructosamine is used to refer to all glycated proteins resulting from the non-enzymatic reaction of glucose with the protein amine groups, $80 \%$ of which correspond to albumin. The measurement of serum fructosamine is used to monitor DM control, as well as glycated hemoglobin (HbA1c), with the advantage that the circulating half-life of albumin is approximately 20 days, while that of hemoglobin is about 120 days. Therefore, the fructosamine dosage reflects a shorter time period than $\mathrm{HbA1c}$, allowing to assess earlier interventions performed in DM treatment (Souza \& Borges, 2018). In the results shown in Figure 3B, it can be seen that the DC, DSTV and DSAC groups had significantly higher fructosamine values than the ND group, but no significant effect of supplementation was seen in diabetic animals.

Plasma total cholesterol and triglyceride values were also evaluated (Figures 3C and 3D), since dyslipidemias are common in patients with $\mathrm{DM}$, because insulin plays an important role in the metabolism of lipoproteins. This hormone is necessary for lipid and lipoprotein synthesis and also for activating lipoprotein lipase which performs intravascular hydrolysis of particles rich in triglycerides (Howard, 1987).

As shown in Figure $3 \mathrm{C}$, no significant differences were observed in the plasma cholesterol concentration between the four animal groups. Regarding the triglyceride values expressed in Figure 3D, the DSAC group showed significantly higher values than the DC group, while DSTV and the other groups did not differ from each other.

Triglycerides represent the majority of fats eaten in a meal. After being hydrolyzed and emulsified, they are absorbed by intestinal cells and transported in the form of chylomicrons by the lymphatic system until they reach the circulation through the thoracic duct. Chylomicrons are hydrolyzed by lipoprotein lipase, an enzyme present in capillary endothelium which is stimulated by insulin. This enzyme is necessary for fatty acids, glycerol and cholesterol present in chylomicrons to be released and absorbed by cells for both storage (which especially occurs in adipose tissue), and for their use. The plasma triglyceride concentration is very sensitive to changes in the diet composition, particularly regarding the quality and quantity of carbohydrates and fats (Faludi et al., 2017).

In Table 2, it can be seen that the three diets used in this work are similar in terms of centesimal composition, with practically the same proportions of proteins, lipids and proteins. Regarding the quantity, it is shown in Figure 1 that the DSTV and DSAC groups ingested a greater amount of feed when compared with the ND and DC groups, which could justify the significant increase in triglyceridemia in the DSAC group given the insulinopenia condition caused by diabetes, as these animals were unable to transform the largest food intake into an increase in body weight (Figure 2).

Figures $3 \mathrm{E}$ and $3 \mathrm{~F}$ show plasma AST (aspartate aminotransferase) and ALT (alanine aminotransferase) concentrations, respectively, which are two enzymes that are liver damage markers. Although the AST values were higher in the DSTV and DSAC groups compared to the ND group, only the DSAC group differed from the DC group. There were no significant differences in ALT values. It is important to note that the serum AST and ALT enzymes may be less representative of the severity of hepatic fat accumulation in diabetic patients (Leite et al., 2014).

Diabetic patients are at increased risk of developing nonalcoholic fatty liver disease (NAFLD). There is an increase in the lipase enzyme sensitive hormone activity in adipose tissue due to the reduction or absence of insulin in type 1 DM, causing a high lipolytic rate and an increase in free fatty acids (FFA) in the blood, and consequently an increase in FFA uptake. hepatocytes. Liver steatosis occurs when the uptake and synthesis of FFA in the liver exceeds its ability to oxidize and export them. Hepatic lipid accumulation can cause toxicity due to inefficient oxidation and the activation of inflammatory pathways; certain lipid metabolites such as diacylglycerol and ceramides can cause cell damage and death, contributing to development of NAFLD (Leite et al., 2014).

Figure 4 shows that the DSTV group had significantly lower values than the DC group. Park \& Cha (2010) obtained similar results in obese mice treated with stevia extract and suggested that stevia has natural ligands which are activators of PPAR $\alpha$ (receptor activated by alpha-type peroxisomal proliferators), as they found an increase in the expression of genes encoding the fatty acid oxidation enzymes in the liver. Therefore, it is possible that the animals in the DSTV group showed a reduction in

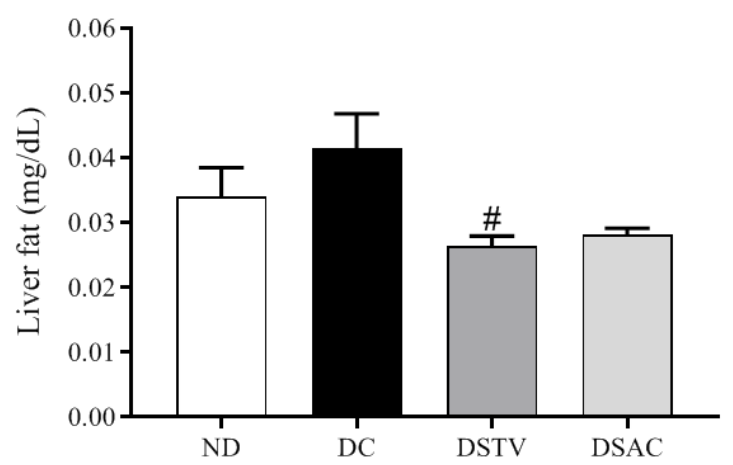

Figure 4. Effect of food supplementation with cereal bars sweetened with stevia leaves pretreated with ethanol (SLPE) or with sucrose on the amount of liver fat (expressed in triglycerides - $\mathrm{mg} \mathrm{dL}^{-1}$ ) of diabetic rats under fasting at night. Data represent the mean \pm SEM. \# Differs from DC; $p<0.05$ analysis of variance followed by the Tukey test. 


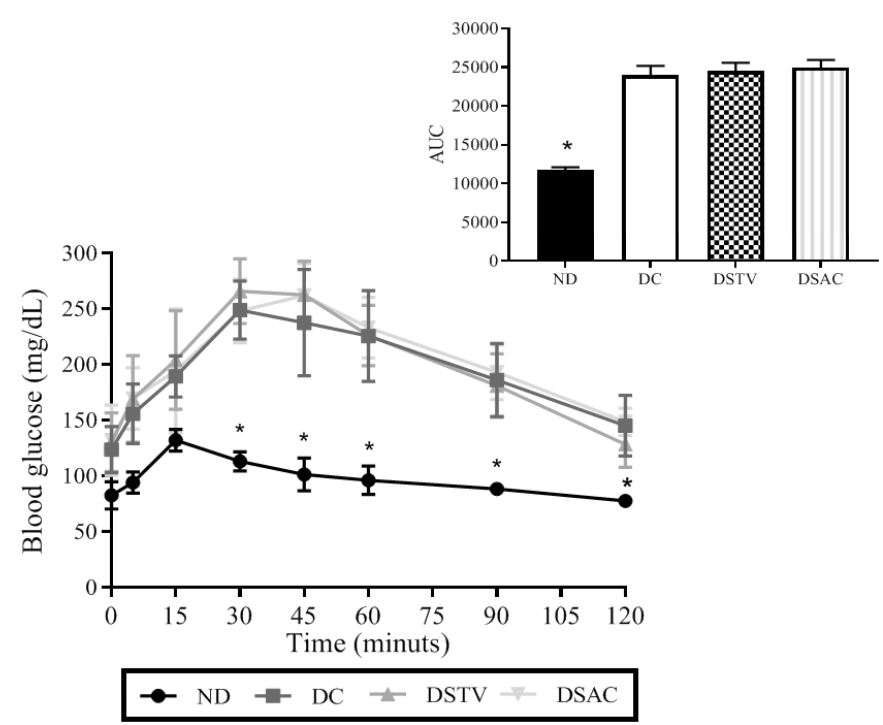

Figure 5. Effect of food supplementation with cereal bars sweetened with stevia leaves pretreated with ethanol (SLPE) or with sucrose in the oral glucose tolerance test (OGTT) of diabetic rats. In particular, the area under the curve (AUC). Data expressed as mean \pm SEM. * Differs from other groups $\mathrm{p}<0.05$ - analysis of variance with Tukey's post-test.

hepatic steatosis when compared with the DC group, as they have greater hepatic capacity to oxidize FFA.

Liver fat deposition is related to lifestyle, particularly to eating habits, and regular consumption of functional foods can offer a viable alternative to reduce the risks of developing diseases such as liver steatosis (Jia \& Xie, 2019).

The three diabetic animal groups showed high glycemic values at all times recorded during the OGTT, with statistically higher area under the curve (AUC) values than the group of nondiabetic animals (Figure 5). Supplementation both with cereal bars sweetened with stevia and sucrose did not significantly interfere in the response of diabetic animals during OGTT.

\section{Conclusion}

The diet supplemented with cereal bars sweetened with SLPE significantly reduced the amount of liver fat in diabetic rats, suggesting the potential for cereal bars sweetened with SLPE to act as a functional food for diabetic patients.

\section{Acknowledgements}

Project financed with resources from the State Secretariat for Science, Technology and Higher Education - SETI - Fundo Paraná; CNPq and CAPES (Financing Code - 001).

\section{Literature Cited}

Castro, A. G. P.; Franco, L. J. Caracterização do consumo de adoçantes alternativos e produtos dietéticos por indivíduos diabéticos. Arquivos Brasileiros de Endocrinologia \& Metabologia, v. 46, n.3, p. 280-289, 2002. https://doi.org/10.1590/S000427302002000300011.
Ciuli, M.; Quirantes-Piné, R.; Spano, N.; Sanna, G.; Borrás-linares, I.; Sefura-Carretero, A. Evaluation of new extraction approaches to obtain phenolic compound-rich extracts from Stevia rebaudiana Bertoni leaves. Industrial Crops and Products,v. 108, p. 106-112, 2017. https://doi.org/10.1016/j.indcrop.2017.06.024.

Dacome, A. S.; Silva, C. C.; Costa, C. E. M, Fontana, J. D.; Adelmann, J.; Costa, S. C. Sweet diterpenic glycosides balance of a new cultivar of Stevia rebaudiana (Bert.) Bertoni: Isolation and quantitative distribution by chromatographic, spectroscopic, and eletrophoretic methods. Process Biochemistry, v. 40, n.11, p. 3587-3594, 2005. https://doi.org/10.1016/j.procbio.2005.03.035.

Faludi, A. A.; Izar, M. C. O.; Saraiva, J. F. K.; Chacra, A. P.; Bianco, H. T.; Afiune Neto, A.; Bertolami, A.; Pereira, A. C.; Lottenberg, A.M.P; Sposito, A.C.; Chagas, A.C.P.; Casella-Filho, A.; Simão, A.F.; Alencar Filho, A.C.; Caramelli, B.; Magalhaes, C.C.; Magnoni, D.; Negrao, C.A.; Ferreira, C.E.S.; Scherr, C.; Feio, C.M.A.; Kovacs, C.; Araújo, D.B.; Calderaro, D.; Gualandro, D.M.; Mello Junior, E.P.; Alexandre, E.R.G.; Sato, I.E.; Moriguchi, E.H.; Rached, F.H.; Santos, F.C.; Cesena, F.H.Y.; Fonseca, F.A.H.; Fonseca, H.A.R.; Xavier, H.T.; Pimentel, I.C.; Giuliano, I.C.B.; Issa, J.S.; Diament, J.; Pesquero, J.B.; Santos, J.E.; Faria Neto, J.R.; Melo Filho, J.X.; Kato, J.T.; Torres, K.P.; Bertolami, M.C.; Assad, M.H.V.; Miname, M.H.; Scartezini, M.; Forti, N.A.; Coelho, O.R.; Maranhão, R.C.; Santos Filho, R.D.; Alves, R.J.; Cassani, R.L.; Betti, R.T.B.; Carvalho, T.; Martinez, T.L.R.; Giraldez, V.Z.R.; Salgado Filho, W. Atualização da diretriz brasileira de dislipidemias e prevenção da aterosclerose - 2017. Arquivo Brasileiros de Cardiologia, v. 109, p. 1-91, 2017. https://doi.org/10.5935/abc.20170121.

Folch, J.; Lees, M.; Stanley, G.H.S. A simple method for the isolation and purification of total lipids from animal tissues. Journal of Biological Chemistry, v. 226, n.1, p. 497-509, 1957. https://www. jbc.org/content/226/1/497.long. 10 Jun. 2020.

Formigoni, M.; Milani, P. G.; Dacome, A. S.; Avíncola, A.S.; Benossi, L.; Santos, V. J.; Pilau, E. J.; Costa, S. C. Stevia rebaudiana leaves pretreated with ethanol and characterization of the ethanolic extract by UPLC-HRMS. Food Chemistry, v. 241, p. 452-459, 2018. https://doi.org/10.1016/j.foodchem.2017.09.022.

Harlev, E.; Nevo, E.; Mirsky, N.; Ofir, R. Antidiabetic attributes of desert and steppic plants: a review. Planta medica, v. 79, p. 425436, 2013. https://doi.org/10.1055/s-0032-1328331.

Howard, B. V. Lipoprotein metabolism in diabetes mellitus. Journal of Lipid Research, v. 28, n.6, p. 613-628, 1987. https://www.jlr.org/ content/28/6/613.full.pdf. 10 Jun. 2020.

Hubert, J.; Borie, N.; Chollet, S.; Perret, J.; Barbet-Massin, C.; Berger, M.; Renault, J. H. Intensified separation of steviol glycosides from a crude aqueous extract of stevia rebaudiana leaves using centrifugal partition chromatography. Plantamedica, v. 81, n.17, p. 1614-1620, 2015. https://doi.org/10.1055/s-0035-1545840.

Jeppesen, P. B.; Gregersen, S.; Alstrup, K. K.; Hermansen, K. Stevioside induces antihyperglycaemic, insulinotropic and glucanostatic effects in vivo: studies in the diabetic Goto-Kakizaki (GK) rats. Phytomedicine, v. 9, n.1, p. 9-14, 2002. https://doi. org/10.1078/0944-7113-00081.

Jia, C.; Xie, M. Attenuation of high-fat diet-induced fatty liver through PPAR $\alpha$ activation by stevioside. Journal of Functional Foods, v. 57, p. 392-398, 2019. https://doi.org/10.1016/j.jff.2019.04.034. 
Leite, N. C.; Villela-Nogueira, C. A.; Cardoso, C. R. L.; Salles, G. F. Non-alcoholic fatty liver disease and diabetes: From physiopathological interplay to diagnosis and treatment. World Journal of Gastroenterol, v. 20, n.26, p. 8377-8392, 2014. https:// doi.org/10.3748/wjg.v20.i26.8377.

Nansseu, J. R.; Fokom-Domgue, J.; Noubiap, J. J.; Balti, E. V.; Sobngwi, E.; Kengne, A. P. Fructosamine measurement for diabetes mellitus diagnosis and monitoring: a systematic review and metaanalysis protocol. BMJ Open, v.5, n.5, e007689, 2015. https://doi. org/10.1136/bmjopen-2015-007689.

Pálsson, R.; Patel, U. D. Cardiovascular complications of diabetic kidney disease. Advances in Chronic Kidney Disease, v. 21, n.3, p. 273-280, 2014. https://doi.org/10.1053/j.ackd.2014.03.003.

Park, J. E.; Cha, Y. S. Stevia rebaudiana Bertoni extract supplementation improves lipid and carnitine profiles in C57BL/6J mice fed a highfat diet. Journal of the Science of Food and Agriculture, v. 90, n.7, p. 1099-1105, 2010. https://doi.org/10.1002/jsfa.3906.

Payne, A. J.; Kaja, S.; Naumchuk, Y.; Kunjukunju, N.; Koulen, P. Antioxidant Drug Therapy Approaches for Neuroprotection in Chronic Diseases of the Retina. International Journal of Molecular Sciences, v. 15, n.2, p. 1865-1886, 2014. https://doi.org/10.3390/ijms15021865.

Pinto, V. R. A. Perfil dos consumidores de barras alimentícias sob perceptivas mercadológica, sensorial e de imagem Corporal. Minas Gerais: Universidade Federal de Viçosa, 2017. 132p. Masters Dissertation. http://www.locus.ufv.br/ handle/123456789/10330. 02 Jun. 2020.

Raskovic, A.; Gavrilovic, M.; Jakovljevic, V.; Sabo, J. Glucose concentration in the blood of intact and alloxan-trated mice after pretreatment with commercial preparations of Stevia rebaudiana (Bertoni). European Journal of Drug Metabolism and Pharmacokinetics, v. 29, p. 87-90, 2004. https://doi.org/10.1007/BF03190581.
Rees, D. A.; Alcolado, J. C. Animal models of diabetes mellitus diabet. Diabetic Medicine, v. 22, n.4, p. 359-370, 2015. https://doi. org/10.1111/j.1464-5491.2005.01499.x.

Silva, M.; Lima, W. G.; Silva, M. E.; Pedrosa, M. L. Efeito da estreptozotocina sobre os perfis glicêmico e lipídico e o estresse oxidativo em hamsters. Arquivos Brasileiros de Endocrinologia e Metabologia, v. 55, n.1, p. 46-53, 2011. https://doi.org/10.1590/ S0004-27302011000100006.

Silva, S. B.; Formigoni, M. A.; Zorzenon, M. R.; Milani, P. G.; Dacome, A. S.; Seixas, F. A. V.; Costa, S. C. Development of diet cereal bar sweetened with stevia leaves pre-treated with ethanol. Food Science and Technology, e19319, 2019. https://doi.org/10.1590/ fst.19319.

Souza, I. D. P.; Borges, K. B. G. Quantificação de frutosamina como parâmetro para o controle do diabetes mellitus. Analisando, v.7, n. 24,2018 . http://www.goldanalisa.com.br/print.asp?id=182. 31 Mar. 2020.

Sponer, P.; Kucera, T.; Brtkova, J.; Srot, J. The management of Charcot midfoot deformities in diabetic patients. Acta Medica (Hradec Králové), v. 56, n.1, p. 3-8, 2013. https://doi. org/10.14712/18059694.2014.30.

Srebernich, S. M.; Meireles, F.; Lourenço, G. Avaliação microbiológica de barras de cereais diet por meio de agente ligante hidrolisado e goma acácia. Revista de Ciências Médicas, v. 20, n.1, p. 5-13, 2011. https://doi.org/10.24220/2318-0897v20n1/2a819.

Vargas, E.; Podder, V.; Carrillo- Sepulveda, M. A. Physiology, glucose transporter type 4 (GLUT4). In: StatPearls [Internet]. Treasure Island: StatPearls Publishing, 2020. https://www.ncbi.nlm.nih. gov/books/NBK537322. 10 Jun. 2020. 